\title{
RACE AND MASCULINITIES IN THE SOUTH AFRICAN MILITARY
}

\author{
Nyameka Mankayi, \\ Human Sciences Research Council (HSRC), \\ Cape Town, South Africal
}

\begin{abstract}
Generally, the military and masculinity are confirmed as harmonious and mutual. For many countries, military service assumes the status of initiation into manhood. In South Africa, for example, in the past, young white men were legally obliged to do military service. This emphasises the importance of focusing on white masculinities within the South African military in this article. Strong parallels with 10 African $^{2}$ male soldiers who also underscored hegemonic masculinity are drawn. The construction of masculinity of young male soldiers is discussed historically and in the present context. Transcriptions of semi-structured interviews with soldiers drawn from a total of 14 participants were qualitatively analysed and are presented to illustrate the themes that emerged in the interviews. The findings suggest that the military encompasses masculine characteristics and defines soldiering as an embodiment of traditional male sex practices. This article concludes that military context and culture exaggerate and emphasise hegemonic masculinity and heterosexuality for male soldiers.
\end{abstract}

\section{Introduction}

The military in South Africa has a long history. Apart from combat experience and conventional warfare participation nationally and internationally, after World War II, military experience also became part of the educational system in white schools in the country (Morrell 2001; Stott 2002; Williams 2003). The first

\footnotetext{
${ }^{1}$ Thanks are due to Prof. A. V. Naidoo and Prof. T. Shefer, who supervised the study from which this article emanated. Financial support from the National Research Foundation is gratefully acknowledged.

${ }^{2}$ Race is differentiated on the basis of the historical apartheid categories black, coloured, Indian and white, while the word 'African' refers to a combination of black, coloured and Indian racial groups.
} 
common defence organisation, the Union Defence Force (UDF), came into being in July 1912. This organisation was transformed into the South African Defence Force (SADF) in the 1960s. The South African National Defence Force (SANDF) replaced the SADF on the eve of the first democratic general election in 1994. This new structure emerged from the decision to integrate ${ }^{3}$ the non-statutory forces of Umkhonto we Sizwe (MK) ${ }^{4}$ and the Azanian People's Liberation Army (APLA) with the Transkei, Bophuthatswana, Venda and Ciskei (TBVC) forces and the SADF (Le Roux 2003; Seegers 1996).

The transition from the SADF to the SANDF was complicated and marred by disagreement, tension and discontent (Le Roux 2003; Ngculu 2003; Stott 2002). Since 1994 while undergoing complex processes of transformation, restructuring and downsizing, the military has been involved in a range of security issues. In both the 1994 and 1999 elections, for example, the SANDF assisted the Independent Electoral Commission in the registration and voting processes (Stott 2002). The military was deployed in high-risk areas around the country to reduce tensions between members of the various political parties and to provide the necessary security on voting days (Stott 2002). The SANDF plays a major role in border patrols, with 23 companies engaged at any one time along South Africa's extensive frontiers. The military also performs a central role in assisting the new South African Police Service in crime-combating operations. Externally, the new South African military has been and still is involved in a number of operations. The SANDF was engaged in peacekeeping missions in Burundi and the Democratic Republic of the Congo (DRC) (Stott 2002). This deployment, officially called the South African Protection Support Detachment, was South Africa's biggest, most expensive and riskiest military mission since 1994 (Stott 2002).

\section{Military service: Conscription}

Militarisation in the 1970s and 1980s impacted on the lives of many South African men. Compulsory military service for conscripted young, fit and white South African men was introduced, resulting in the imprinting of the soldier image as masculine in popular white culture (Du Pisani 2001). The period of conscription

${ }^{3}$ Integration normally refers to the process by which armed forces and military traditions are merged into one defence force at the end of a war or civil conflict.

${ }^{4}$ Umkhonto we Sizwe was the military wing of the African National Congress (ANC). 
varied through the years. It began with a six-month call-up in the late 1950s and early 1960s, and was then increased to nine months, and later to two years. For the better part of the conscription period, tough and crude professionals, many of whom were corporals and sergeant majors, controlled these young men's lives (Du Pisani 2001). Enloe (2000) states that young men of draftable age during the 1980 s were propelled toward military service, not only by conscription law, but also by a desire to be seen as manly and by the fear of being labelled by others as "cowards" or pejoratively as "faggots" or "yellow. Du Pisani (2001) reports that some white men resisted the call-up. As a result some left the country. An interesting question relates to what the implications of this were for masculinity. Conscription has been constructed as a crucial system for reproducing/ensuring 'normal' adult masculinity (Enloe 2000). In many cases this image are reinforced by the media - also in South Africa (Craig 2008). Compulsory military service has been marked by its effectiveness as a socialisation agent. Service to the nation or "national service" was often portrayed as a necessary experience that transformed young white conscripted soldiers into responsible men who can support their families and cooperate in organised civil society (Du Pisani 2001; Enloe 2000). An honourable discharge meant the end of 'adolescent wandering' and youthful resistance to the social order (Jo 1997). Cock (2001) contends that the SADF was a crucial source of ideas about appropriate behaviour for white South African men. The military successes of the $\mathrm{SADF}$ in the Bush $\mathrm{War}^{5}$ in northern Namibia and Angola were presented by the media in such a way that the image of the warrior hero was nurtured and revered (Batley 2007; Liebenberg 2009).

The long history of masculinity and militarism is not unique to South Africa. The link between militarisation and masculinisation is universal. Men have since time immemorial and in every society been expected and socialised to be the protectors and fighters. In South Korea, for example, many people believe that the required years of conscription are a significant turning point in the acquisition of a trained muscular body and male maturity (Jo 1997).

\section{Military service: A calling or a job?}

A global shift from conscription to voluntary service seemed to have become a norm (Ferrari \& Oliva 2008). The shift from mandatory conscription to volunteer armies has provided many men with the opportunity to combine armed

5 'Bush War' refers to the armed conflict or border and cross-border war between the SADF and neighbouring military and civilian groups. 
masculinity with the masculinity of the breadwinner (Snyder 1999). In the USA, for example, military service is perceived as a path for social mobility, and most soldiers enlist for economic reasons (Sasson-Levy 2003). Joining the "service" is now a voluntary act in many countries, including South Africa. In contemporary South Africa, many people join the military for job security or educational opportunities that will provide the financial and promotional prospects needed to gain material success (Heinecken 1994; Heinecken \& Khanyile 1996). The study by Heinecken and Khanyile (1996) indicated that 78,7\% of soldiers polled joined the military for job security with fringe benefits, together with a preference for discipline, orderliness, uniformity and cohesiveness. Approximately 60\% indicated an interest in weaponry as a motivating factor. Caforio and Nuciari (1994) concur that job security and career prospects motivate many people to join the military. They further point out that most occupational officers come from lower socioeconomic backgrounds, and therefore represent the broader population and not elite social groups, as was the case in previous times. It is important to note that there is also a connection between job security and traditional masculinity, reflecting the men as both providers and protectors.

\section{Masculinity in general}

Contemporary writings on gender and masculinity point to the historical and cultural specificity of the concept and the lived experience of masculinity. Most research done in the field of masculinity suggests that there are multiple forms of masculinity, that there are hierarchical and hegemonic forms of masculinity and that masculinities are actively produced and created in specific historical circumstances (Connell 1995; 2000). This suggests that no one type of masculinity has been identified everywhere. Since different cultures and different periods of history construct gender differently, we need to speak of masculinities and not masculinity (Connell 1995; 2000, Cornwall \& Lindisfarne 1994; Skelton 1997; Swain 2002). Diverse forms of masculinity clearly exist within a given setting, be it social or institutional. Given that historical and cultural circumstances play a role in the construction of masculinity, it is necessary to specify that this article presents the construction of masculinity in the military by reflecting the differences and similarities of white and African soldiers in the post-apartheid era in South Africa.

\section{Masculinity in the military}


Barrett (1996) states that militaries all over the world have defined soldiering as an embodiment of traditional male sex role behaviours such as heterosexuality, braveness, aggression, sexual virility, independence and adventurousness. They have therefore socialised millions of men according to a traditional blueprint. An interesting question is how one reconciles the notion of traditional blueprint with that of the historically and socially variable masculine constructions highlighted above? Hence, there has been a long association between the military and dominant/hegemonic images of masculinity. Yet militaries are not merely random collections of men (or women). They are also stratified according to gender, race, ethnicity, class and rank.

Ethnic composition of militaries, for example, reflects the dominant ideologies and policies of the regime in power. This is a primary factor in determining who is in the military and who is not, who is in the air force rather than in the army, and who becomes a commissioned officer and who does not. In the apartheid days, the SADF was a vehicle for white dominance, especially at the higher echelons. Coloured and Indian men were recruited and given weapons training purely for self-defence in war times. However, these soldiers were not permitted to perform combat roles and were confined to auxiliary duties. Black men were recruited and trained for armed guard duty at military installations or as drivers, clerks, store men and dog handlers (Enloe 1975). These different job descriptions according to racial groups point to the different masculinities (subordinate and dominant) that exist within the militaries. White participants had dominant ones. Across disciplines, volumes have been written about the role of the military in the construction of masculinities, but it seems that little has been said about soldiers in the military within the historical and present context in which they join the military, and how this may relate to their construction of masculinity. This also applies to the case of young white South Africans, which triggered the interest in this article.

\section{The study}

This article is the product of an analysis and interpretation of 14 transcribed interviews held with male soldiers from different racial groups. The selected group reveal diverse stories, experiences and ways in which they construct their masculinities in an institution that was previously controlled by the white government. All 14 participants were enrolled in a tertiary institution as undergraduate and postgraduate students while pursuing a career in the military. They were all junior officers with ranks ranging from lieutenant to captain. The 
participants were between the ages of 23 and 33 years - a group regarded as sexually active and at high risk of HIV infection (Heinecken 2001). They all identified themselves as heterosexual. They have all been in the military for more than four years. Although not a criterion used in their selection for the study, all white participants had fathers who were conscripted during the apartheid era and all came from traditional white public schools.

One-and-a-half to two-hour interviews were conducted. Interviews were qualitatively analysed using Edley and Wetherell's (1997) interpretative discourse analysis. The author did not assume one form of masculinity for all participants, but remained aware of the defining power of other social identities such as race, class, age, marital status, religious backgrounds and so forth. In the following section, excerpts from the interviews are presented to illustrate the discursive themes that emerged in the interviews. Qualitative research implies an undertaking and an obligation not to harm research participants and to maintain anonymity, therefore pseudonyms are used to identify participants and detailed demographic information of this small sample is omitted in order not to compromise confidentiality.

\section{Findings and discussion}

The central question posed was: How are masculine constructions acted out by the diverse group of male soldiers? Themes related to this question are discussed below. Caution regarding the findings is necessary, since the analysis and interpretation are by no means exhaustive and the sample was relatively small. The discourses portrayed cannot be generalised to all men in the military, but rather illustrate a slice of life reflected by the research participants. What should be noted is that the participants' constructions of masculinity and sexuality call for investigation, as these constructions have concrete implications for the lives of both young women and men (black and white) in the SANDF and broader society. It should be noted that even though there are differences, some constructions of masculinity are similar. However, in some cases an issue of time interval lapse ${ }^{6}$ between the two groups' constructions exists.

Calling versus job security

A study of masculine constructions has to take social background into account, and, as Dowsett (2003) asserts, historical factors need to be investigated to

\footnotetext{
${ }^{6}$ Interval lapse refers to periodisation and change from the apartheid to the post-
} apartheid era. 
better understand masculinity. Soldiers from different racial groups with different historical and social backgrounds join the military for different reasons; as a result, they construct masculinity differently. All the white participants in this study expressed the belief that soldiering is a "calling" and not just a job. This reference to the "calling" of soldiering was often central in the stories about how they came to their current occupation. Participants emphasised that soldiering is about commitment and love, and not just job security. This is shown in the following excerpts from white middleclass participants whose fathers were their role models, as they were also soldiers:

Simon: I've always believed that [...] soldiering is not a job, it's a calling. You don't just come here because you don't get work from the outside. People like that irritate me. You don't just come here for a cheque, you come here because that is what you want to do.

Gerhard: Soldiering is not really a job, it's a way of living. You are either [...] meant to be a soldier, or you are wasting your own time and the state's time and money.

Johan: It's a calling. It's not working in a job, it's doing something to make a difference [...] not only to the military, but to the country. [...] I enjoy it [the military]. I enjoy it very much.

For these participants, joining the military was not driven by the desire for socio-economic status or material benefits only. The historical context of race and its relationship to the SADF was also implicated. For example, prior to 1994, young white men were encouraged to experience the macho culture that prevailed in the military. Drawing on a human rights discourse, there was a level of tolerance among participants for those who, despite joining the military for job security or social mobility, were committed:

Gerhard: There's a lot of people trying to or going out of their way to make me negative, [...] but if you are, if you've got the positive attitude, then I can't see any problems for you.

Johan: As long as people are still willing to go the extra mile, and don't see it as a nine to five job, or a nine to four job. That's just not the type of attitude that I like to see. As long as people are committed to their work and working hard and making a difference while they 
are in the military, though they might see it as a stepping stone, whatever. That's what I would like to see. I mean, anybody who enjoys the military and says but I'm going to leave it [...], does his work and does it properly, I have no problem with such guys. Because he might have a higher calling and the military is just a way for him to serve in the short time.

Simon also expressed patience for individuals who join the military for personal gain.

Simon: Unfortunately, you get too many people like that join the military for a "cheque")... But I believe that one must do the best job that [one] can.

As Heinecken and Khanyile (1996) found, a majority of soldiers join the military for job security. Findings of this study suggest the same. White participants advocated commitment, even if it was not every man's dream to be a soldier. While the participants quoted above highlighted different concerns or wishes, they all appeared to construct masculinity around responsibility and commitment, in many ways reflecting traditional notions of successful men as mature, rational and emotionally and financially independent (Nagel 1998).

Findings from this study also suggest that the African participants joined the military primarily for socio-economic reasons:

Thando: I tried to go to varsity, I was accepted in two institutions ... but I had no money to study, [...] I decided to go to this security company, and then the Defence Force.

Clearly, joining the military was not this participant's first choice, but due to his socio-economic circumstances he could not afford to enrol at a tertiary institution. This excerpt again confirms Heinecken and Khanyile's (1996) argument of people who join the military for career prospects. Interestingly, for Sam, a coloured participant from a low socio-economic background, joining the military was about the masculine imperative of needing to be responsible and to provide for his family. He expressed powerful emotions about how men neglect this responsibility. This was an important discourse on responsibility and frustration if men are not able to provide financially for their families: 
Sam: It breaks my heart to see how some families suffer because the man is irresponsible [...]. I can't stand it. That's why I came here, I just want to carry on, I just walk away, because I can't stand it, I can't handle it.

Joining the military for this participant was a paradox. On the one hand, he was running away from problems (running away does not symbolise masculinity), while on the other hand, joining the military helped him attain power that would demonstrate responsibility (exhibiting masculinity). Providing for one's family has long been understood as a major focus point for the construction of masculine identities (Collinson \& Hearn 1994; Connell 1995; Sasson-Levy 2003). The military encompasses this masculine characteristic (Morrel 2001). It is worth pointing out that most of the African participants had settled in the military and appreciated it for the same reasons (representing the country, positive male identity) as their white colleagues. Thus, one may argue that the process of racialisation and its intersection with masculine identity is fluid and that variations reflect changes in politics.

Racialisation and hierarchy in the military

Historically, soldiering in South Africa benefitted white male soldiers. Due to the reported tension and dissatisfaction within the SANDF, some white soldiers left the system, as they struggled with accepting their black counterparts (Ngculu 2003). Likewise, in this study, participants stated that many white men had left, and the commitment of those still within the system was questioned:

Johan: A lot of people don't understand that people can still be in the military and be passionate about it, especially if you're a white guy these days.

Simon: ... a lot of whites have left. It just becomes too difficult to be a white man in the army these days. So a lot of them have left and a lot of [...] My generation type guys and a lot of them do not really want to work with the blacks.

On the one hand, these extracts reflect the dominant ideology/discourse of superiority held by some white male soldiers. There were white men who no longer felt a sense of belonging in the military. Some white soldiers from the SADF resisted change and left the new SANDF system, as they could not tolerate having black colleagues. This suggests that some white men still drew on an apartheid 
paradigm discourse and consequently viewed themselves in a historical context. This also mirrors reports that state that the integration of the SADF and the SANDF was marred by strain and unhappiness (Le Roux 2003; Ngculu 2003; Stott 2002), as highlighted above. An example given was of SADF soldiers who struggled with accepting their counterparts, the Umkhonto we Sizwe soldiers, as equals (Ngculu 2003). On the other hand, the extracts demonstrate the participants' love for and commitment to the military. This suggests that there were white male soldiers who were open to change, and who negotiated and rejected aspects of constructing, negotiating and reconstructing their masculine selves among their immediate African male peer groups. The extracts above illustrate how institutions may construct multiple identities, that is, constructing selves with those who share the same values and culture as one's own or who do not have a similar background. Other white soldiers might have left because affirmative action limited their career possibilities - something that this study did not interrogate.

According to Jeff,

[w] hites think they are the cleverest people that God has given South Africa. That only they can make the right decisions, and this goes more to the Afrikaner. Within the white community there [are] still splits. If you Afrikaner, you English, you Czech, you true Dutch, as you know. But they personally, especially the Afrikaner, because the military and especially the army's dominated by the Afrikaner as such and they, as from what I've picked up, personally feel that they are a gift to the country, and whatever they say is and can only be the right thing. The coloured people have always been in the middle, they accept it because they have to, that is how they feel, and I would refer to them as "they" because I personally see people as individuals ... I've been classified due to a corrupt system, although it cannot be proven, but it's a system that's placed that classification, like black, African, coloured, Indian, on an individual.

This excerpt illustrates the argument that geographical borders, race, ethnicity, culture and class play a crucial role in the construction of identities (Caplan 1987; Lees 1986; Shefer 1999). Similar to other excerpts quoted above, this one further illustrates that masculinities are actively produced and that masculinities are created in specific historical circumstances (Connell 1995; 2000). In South Africa, and particularly in the military, race plays a major role in determining who is superior to others. The superiority of white soldiers points to the preferred 
characteristic of dominant masculinity. Superiority and powerfulness are some of the dominant masculine characteristics to which men strive.

Written and unwritten military culture and tradition

Tradition is defined as a customary pattern of thought or practices held by an identifiable group of people. The military also has its own official and social traditions. These customs or elements of institutional culture are seldom written down. Even though these traditions might not be familiar to the civilians, the soldiers regard them in a serious light ${ }^{7}$. Some of the ways in which traditions are expressed, particularly in the military, are the uniform soldiers wear, the things they do in their corps (a body of troops working together) and the things they say, as illustrated below:

Simon: I have never been one who talks shop to civilians, that is to talk about my work, even when I was 18, 19 years old, I always looked down on the guys who stand at the bar, try and pick up a lady by using the fact that he is in the army.

This participant, who joined the military when he was a teenager, points to the attainment of power that is achieved through wearing a uniform. Wearing a uniform and going to the bar for him were associated with power and access to women. It further points to the important link between dressing and attracting women (heterosexuality), which is another key component of hegemonic masculinity (Connell 2000). A uniform particularly demonstrates military status (Craig 2005). This status suggests strength and braveness and therefore dominant masculinity. A feeling of superiority when in uniform was confirmed by Gerhard:

And it's a nice feeling to be in uniform, I think even nicer if you're walking between civilians on the street and the people are looking at you [...] For me it's like feeling like you could be the role model of the world, everyone wants to be like you and if you're, especially at Stellenbosch, okay, I would say, I think it's more the white guys probably.

$7 \quad$ Anon. (http://www.globalsecurity.org/military/library/policy/army/fm/721-13/chap4.htm). Accessed 12/08/2010. 
The excerpt suggests that the military uniform creates a sense of pride for white male soldiers, as it implies the specialness in soldiering or cooperating in civil matters (Enloe 2000), but also a sense of strength through observable symbols, primarily that of the uniform.

As highlighted, some of the white soldiers still derived pride when in uniform, but this was not true for all:

Simon: Times have changed; the days where you'll go to town and be proud of being in uniform in the cities have changed, you can't do it anymore. You actually go to your room, put on civilian clothes and then go to town.

Contrary to the above sentiment, a black participant expressed a feeling of being uncomfortable with wearing his uniform, especially when entering black communities:

Tulani: When I joined SADF it was torture, especially in Soweto. It was not easy for a person to join SADF until 1996. In '96 because now forces integrated to make people tend to understand that soldiers from outside integrated and now it was a new force, the SANDF. I started for the first time in 1999 to go home in uniform. I went once at night (the first time I went home was at night).

Similarly, Thando was scared of wearing his uniform because of the racial stigma attached to it:

$J a$, it was quite scary because I remember there was a time when you could not go on buses and trains to your house in uniform. Now it is exciting.

The excerpts from both black and white participants show the challenges experienced by some participants in the construction of their male identity in the new dispensation. The above excerpts highlight the racial and political tensions that existed during the apartheid era and a few years thereafter. Issues of incomplete transition from the SADF to the SANDF implicate race and identity. The tensions might explain why African participants in this study joined the military for socioeconomic reasons as opposed to a "calling". Other studies have found that many people join the military for job security, career and financial prospects (Caforio \& 
Nuciari 1994; Heinecken 1994; Heinecken \& Khanyile 1996). It has been shown above that, before the full integration of militaries in South Africa, the military uniform was constructed differently by white and black soldiers. For white soldiers, it meant being a proud South African, whereas for black soldiers, it meant compromising the freedom of black people. This suggests that even though dressing modifies bodies and therefore constructs masculine identities (Connell 2000; McFadden 1992), historical factors do come into play. This highlights the different constructions of masculinity between white and black soldiers that vary at different times and are therefore historically bound (Mosse 1993).

Nowadays it is not only soldiers who like uniforms, but also those closer to them.

Thsepo: I phoned her [mother] from Bloem, and I said you know I'm in the army. She was furious [laughs] but during my first day when I was here [...] Ja, so she saw the uniform ... she said you look beautiful in the uniform

The extract below shows how military uniforms are used for benchmarking masculinities against each other. The colour (white) and the activities of those (from the Navy) in that colour were undermined by other arms of services:

Gerhard: The army guys always, they are joking with the navy guys, they say, ja, you know you're a bunch of gay guys there in your white uniforms and [...] they are a bunch of singers [...] they call themselves the Village People, they sing that song [sings] YMCA, YMCA, you know that song?

The above extract further demonstrates the significance of not just the military uniform but also the type or colour of the uniform in the construction of masculinity. A comment about the white uniform suggested that gay men were particularly "othered" in the military given the prevailing masculinist, heteronormative culture:

Sam: You can't be a soldier if you are a homosexual.

Homosexuality exemplifies subordinate masculinity to soldiers, irrespective of their race. The discourse of competition among soldiers was articulated as a major facet of the construction of masculinity. Similarly, Barrett, 
(1996) in his study of the US Navy, reported that masculinity was deeply embedded in military practices and ideologies.

A discourse of competition continued among the participants:

Gerhard: Pantser guys are the best, they've got these big tanks and they are driving it and they've got this big gun and they go into length explaining to you how many millimetres and the type of ammunition that they are firing and how tough their training is [...] intelligence, we are the jackals we know everything, and they we say ah no, you armour guys you just sit there in your tank, you don't know what's going on you just shoot your gun, but we have to tell you where your gun is shooting.

Simon: Me, I'm a paratrooper; I'm a man [boasting]. I enjoy being a man. I don't want to be a feminine man. I want to be a man.

Characteristics such as physicality, risk and intelligence all boost the sense of masculinity.

Customs do not only include positive actions, but also taboos and things that people avoid ${ }^{8}$. Participants also referred to military tradition that could be regarded as an unhealthy lifestyle:

Gerhard: I think every military has got a type of unwritten culture, if you can call it that, or let's just call it a culture, in which men, especially men, but I've seen ladies also, fall into that trap, where men are very, when it comes to personal, where they just let go. Like I already mentioned, religion is not big here in the military, even though we have chaplain's periods, things like that, religion is not big in the military. The guys start to drink very heavily, guys start to smoke very heavily, and they start to experiment with drugs.

Alcohol is indeed regarded as a significant problem in the military. Alcohol drinking and sex are reported to be rife during deployment, especially among the lower ranks. This is confirmed by Mankayi (2006) as well as the participants in this study:

$8 \quad$ Anon. (http://www.globalsecurity.org/military/library/policy/army/fm/721-13/chap4.htm). Accessed 12/07/2010. 
Gerhard: You can't tell the people, listen, we prevent you from going out of the camp, because then troops get drunk in the camp and then maybe they get hold of ammunition and they start shooting because they want to have a party that night.

Simon: A guy will go out, he will screw two chicks in one night, the next he's a man. It's unfortunately the way it is. That is the way ... it's life. Unfortunately it is that way. Ja, a guy that can play the field is considered manly. That is just reality.

The last extract leaves little to the imagination, likening the experience of playing in a field, presumably two matches in one day, with the excitement of sex, especially with different women. In a quintessentially masculine metaphor, women's bodies were conflated with the sports field, both bringing excitement and achievement of masculine identity. Shefer and Mankayi (2007) underscore this in their findings in which women are conflated with military weapons. Some participants deal with pressure by drawing on religious injunctions, whereby abstaining from alcohol and avoiding sex until marriage are viewed as signs of masculinity. Men in this discourse proved their masculinity by sticking to these principles:

Johan: I define manliness more in terms of how you ... it's very religious, but how you submit your life to God's principles, because being a man is more being disciplined and sacrificing than doing what you want to do. [...] I think few men are willing to sacrifice when they are young, to say I won't drink or I won't sleep around, I won't abuse women, I won't go into relationships where I know a lady will get hurt but I have no intention of marrying her.

Gerhard: There, there's a lot of guys that think that being a man [...] means that you must impress the ladies the whole time and that you must be at the heart of every party and you must be able to drink until you drop, and try not to drop while you're drinking.

These participants drew their constructions of masculinity from marginalised discourses, just as the literature shows that "housebound" men signify a subordinate masculinity in modern cultures (Murnen, Wright \& Kaluzy 2002). The marginalised view of not seeking many partners acknowledges the multiplicity of 
masculinities, in this instance facilitated by a local religious context (Cheng 1999; Connell 2002; Hearn 1996; Morrell 1998; Wetherell \& Edley 1999). Both Johan and Gerhard highlighted that alcohol consumption symbolises manhood for some men. Gerhard further pointed out the motivation of mastering drinking ("drink until you drop, and try not to drop while you're drinking"). This is confirmed by Van Hoven and Horschelman (2005), who posit that the drinking practice is perceived as a site in which power and legitimacy of masculinity are cemented, thus claiming a space for men.

\section{Leadership and masculinity}

Toughness and leadership are associated with manhood. Leadership as a form of exerting power and control over other people is crucial in maintaining hegemonic masculinity (Du Pisani 2001). Leadership is crucial in the military, as the military system uses a rank hierarchy that clearly draws boundaries between seniors and subordinates. This rank hierarchy is visible to everyone. It appeared that some white participants who still enjoyed the military were in leadership positions and enjoyed the recognition:

Simon: But like I said, about that thing of earning respect, so I received it, and ... and it's cool. I can give a guy shit and he accepts it coming from me, if someone else does the same thing, he became very offended. I can walk to one of the troops and ask what the hell are you doing, why are you doing this, can you see there are about six guys in front of you who'll do the same thing. Why do you not do the same!

The quote above underlines that the construction of manhood (masculinity) hinges on control and, ultimately, power (Connell 1995). Further, by linking leadership and respect, this excerpt supports the notion that one cannot be a leader without being assertive or aggressive and in control. This excerpt further demonstrates the successful use of hierarchy in the military to reproduce subordinate and dominant masculinities. The language of training contributed to these reproductions:

Johan: We did PT with them [juniors] in the morning, but obviously you are reminded of that experience that you had, being given a hard time, but I never had the [...] and people have told me that they were glad to see that, although in the military I cannot shout at people and 
mistreat them, [at the same time] I believe in very hard and tough training.

These excerpts show different communication styles in management, which still produced satisfactory responses from subordinates. Likewise, the leaders had also received such tough training before from those who were senior to them and responsible for their training:

Simon: I personally think once you get to the army, you become completely different. I definitely became matured in the Defence Force from day one. [...] At school, I was shit, shit really. But in the army it is different. Well, you can have problems with authority and it doesn't mean they will take your shit.

The military hierarchy and its training are perceived as a context that has brought some sense of maturity. The requirements are a high level of respect for leaders, rank structures and authority; adherence to rules; a self-image of moral superiority; and the imperative to place people in separate compartments by classifying them as different (Du Pisani 2001). What then is the relationship between masculinity and subordination to orders, given that soldiers must have the capacity to be violent? On the one hand, soldiers must have combat ability, which represents the ultimate expression of masculinity. Yet, on the other hand, being disciplined and obeying orders require a heavy dose of submissiveness, or perhaps a fluid masculinity linked to the specific setting and people present within that setting. This dualism sheds light on the complexity of multiple identities embodied in the military. It also symbolises the ranking of power relations among soldiers, which might result in different ways of constructing masculinity.

\section{Conclusion}

Local and institutional context plays a crucial role in constructions of masculinity and sexuality. Masculine culture, for example, is deeply embedded in South Africa and cuts across racial and ethnic groups (Shefer 1999). Further, our political climate has an impact on perceptions and how masculinities are viewed. This is particularly true for the military, which has historically been divided along lines of racial and gender inequality (Enloe 1975; Frankel 2000). This study shows associations of soldiering with apartheid articulated by white participants, who found it hard to be in a racially integrated military. The findings further suggest that despite race, these soldiers were committed to the military and attained a sense of 
masculine attainment. This masculine achievement had different meanings for the men. For some, the military presented a work opportunity. However, the reasons why these white and African men joined the military were influenced by historical and social factors. For the white men, it was a means to prove commitment and loyalty, while for the African men it was for job security, which also symbolised an element of masculinity. The end result, despite a different departure point, is that masculine identity is strengthened by the common culture of the military.

\section{References}

Barrett, F.J. 1996. The organizational construction of hegemonic masculinity: The case of the US Navy. Gender, Work and Organization 3(3):129-142.

Batley, K. (ed.). 2008. A secret burden: The Border War. Cape Town: Jonathan Ball.

Caforio, G. \& Nuciari, M. 1994. The officer profession: Ideal type. Current Sociology 42(3):49 - 61.

Caplan, P. 1987. The cultural construction of sexuality. New York: Tavistock.

Cheng, C. 1999. Marginalized masculinities and hegemonic masculinity: An introduction. The Journal of Men's Studies 7(13):295-314.

Cock, J. 2001. Guns, violence and masculinity in contemporary South Africa. In R. Morrell (ed.). Changing men in Southern Africa. Pietermaritzburg: University of Natal Press: 43-46.

Collinson, D. \& Hearn, J. 1994. Naming men as men: Implications for work, organization and management. Gender, Work and Organization 1(1):2-22.

Connell, R.W. 1995. Masculinities. Cambridge: Polity Press.

Connell, R.W. 2000. The men and the boys. Berkeley: University of California Press.

Connell, R.W. 2002. Gender. Cambridge: Polity Press.

Cornwall, A. \& Lindisfarne, N. (eds.). 1994. Dislocating masculinity: Comparative ethnographies. London: Routledge. 
Craig, D. 2008. Total justification: Ideological manipulation and South Africa's Border War. In G. Baines \& P. Vale (eds.). Beyond the Border War. Pretoria: University Press: 56-74.

Craig, J. 2005. Uniforms exposed: From conformity to transgression. Stanford. Stanford University Press.

Dowsett, G.W. 2003. Some considerations on sexuality and gender in the context of Aids. Reproductive Health Matters 11(22):21-29.

Du Pisani, K. 2001. Puritanism transformed: Afrikaner masculinities in the apartheid and post-apartheid period. In R. Morrell (ed.). Changing men in Southern Africa. Pietermaritzburg: University of Natal Press: 157-175.

Edley, N. \& Wetherell, M. 1997. Jockeying for position: The construction of masculine identities. Discourse and Society 8:203-217.

Enloe, C. 1975. The politics of pollution in a comparative perspective: Ecology and power in four nations. New York: McKay.

Enloe, C. 2000. Manoeuvres: The international politics of women's lives. Berkeley: University of California Press.

Ferrari, G. \& Oliva, G. 2008. The Italian army and conscription. Spoleto: General Affairs Department and Communications Office, Italian Defence Force.

Frankel, P. 2000. Marching to the millennium: The birth, development and transformation of the South African National Defence Force. Pretoria: South African Defence Force Communication Service.

Hearn, J. 1996. Is masculinity dead? A critique of the concept of masculinity. In M. Mac an Ghaill (ed.). Understanding masculinities: Social relations and cultural arenas. Buckingham: Open University Press: 202-217.

Heinecken, L. 1994. Soldiers and employee rights: South African trends issues. Strategic Review for Southern Africa XVI(2): 77-93.

Heinecken, L. 2001. Living in terror: The looming security threat to Southern Africa. African Security Review 10(4):7-18. 
Heinecken, L. \& Khanyile, M. 1996. Institutional/occupational orientations of students at the SA Military Academy: Report on preliminary findings. Centre for Military Studies, Military Academy, Saldanha.

Jo, S. 1997. Military culture and men in Korean social research. Women Studies Review 12(4):26-54.

Lees, S. 1986. Losing out: Sexuality and adolescent girls. London: Hutchinson.

Le Roux, L. 2003. The South African National Defence Force and its involvement in the Defence Review process. In R. Williams, G. Cawthra \& D. Abrahams (eds.). Ourselves to know: Civil military relations and defence transformation in Southern Africa. Pretoria: Institute for Security Studies: 153-170.

Liebenberg, I. 2009. Beyond the border war: New perspectives on southern Africa's late cold war conflicts. Scientia Militaria. South African Journal of Military Studies 37(2):124-130.

Mankayi, N. 2006. Male constructs and resistance to women in the military. Scientia Militaria. South African Journal of Military Studies 34(2):44-64.

McFadden, P. 1992. Sex, sexuality and the problems of Aids in Africa. In R. Meena (ed.). Gender in Southern Africa: Conceptual and theoretical issues. Harare: SAPES: $157-195$.

Morrell, R. 1998. Of boys and men: Masculinity and gender in Southern African studies. Journal of Southern African Studies 24(4):605-635.

Morrell, R. 2001. From boys to gentlemen: Settler masculinity in colonial Natal 1880-1920. Pretoria: Unisa Press.

Mosse, J.C. 1993. Half the world, half the chance: An introduction to gender and development. Oxford: Oxfam.

Murnen, S.K., Wright, C. \& Kaluzy, G. 2002. If "boys will be boys", then girls will be victims? A meta-analytic review of the research that relates masculine ideology to sexual aggression. Sex Roles: A Journal of Research 17:359-370.

Nagel, J. 1998. Masculinity and nationalism: Gender and sexuality in the making of nations. Ethnic \& Racial Studies 21(2):242-270. 
Ngculu, J. 2003. The role of Umkhonto we Sizwe in the creation of a democratic civil-military relations tradition. In R. Williams, G. Cawthra \& D. Abrahams (eds.). Our selves to know: Civil military relations and defence transformation in Southern Africa. Pretoria: Institute for Security Studies: 177-188.

Sasson-Levy, O. 2003. Military, masculinity, and citizenship: Tensions and contradictions in the experience of blue-collar soldiers. Identities: Global Studies in Culture and Power 10:319-345.

Seegers, A. 1996. The military in the making of modern South Africa. London: Taurus.

Shefer, T. 1999. Discourses of heterosexual subjectivity and negotiation. Unpublished doctoral dissertation, University of the Western Cape, Bellville.

Shefer, T. \& Mankayi, N. 2007. The (hetero)sexualisation of the military and the militarisation of (hetero)sex: Discourses on male (hetero)sexual practices among a group of young men in the South African military. Sexualities 10(2):189-207.

Skelton, C. 1997. Primary boys and hegemonic masculinities. British Journal of Sociology of Education 18(3):349-369.

Snyder, C. 1999. Citizen-soldier and manly warriors: Military service and gender in the civic republic tradition. Lanham: Rowman \& Littlefield.

Stott, N. 2002. From the SADF to the SANDF: Safeguarding South Africa for a better life for all? Violence and Transition Series No. 7 (Monograph).

Swain, J. 2002. The resources and strategies boys use to establish status in junior school without competitive sport. Discourse: Studies in the Cultural Politics of Education 23(1):91-101.

Van Hoven, B. \& Horschelmann, K. 2005. Spaces of masculinities. London: Routledge. 
Wetherell, M. \& Edley, N. 1999. Negotiating hegemonic masculinity: Imaginary positions and psycho-discursive practices. Feminism and Psychology $9(3): 335-356$.

Williams, R. 2003. Conclusion: Mapping new African civil-military relations. In R. Williams, G. Cawthra \& D. Abrahams (eds.). Our selves to know: Civil military Relations and Defence Transformation in Southern Africa. Pretoria: Institute for Security Studies: 265-281.

Web:

The Soldier's Guide 2003. Headquarters Department of the Army, US. Available at: http://www.globalsecurity.org/military/library/policy/army/fm/7-21-13/chap4.htm retrieved $2 / 18 / 2010$ 